\title{
The ability of the rumen ciliate, Diploplastron affine, to digest polysaccharides from fungal and bacterial cell walls
}

\author{
G. Belżecki ${ }^{1}$ and T. Michałowski \\ The Kielanowski Institute of Animal Physiology and Nutrition, \\ Polish Academy of Sciences \\ 05-110 Jabłonna, Poland
}

\begin{abstract}
Rumen ciliates Diploplastron affine were isolated from the rumen and grown in vitro in a medium supplemented with different doses of chitin. The number of cultured ciliates was positively correlated with the chitin dose. The protozoal crude enzyme preparation obtained from bacteria-free ciliates exhibited chitinase as well as chitobiase activity. The ability to degrade murein was also detected. It is concluded that chitin could be utilized by protozoa as an additional source of available energy.
\end{abstract}

KEY WORDS: rumen ciliates, digestion, chitin, murein

\section{INTRODUCTION}

Rumen ciliates engulf large amounts of fungal zoospores and bacteria (Williams and Coleman, 1992). The cell walls of these organisms are rich in chitin and murein, respectively. Both polysaccharides are thus a potentially important source of energy. The ability of particular species of rumen protozoa to digest and metabolize chitin and murein is, however, poorly recognized (Morgavi et al., 1996). The objective of our study was to examine the ability of the ciliate, Diploplastron affine, to use chitin for growth and to determine its chitinolytic and mureinolytic properties.

\footnotetext{
${ }^{1}$ Corresponding author: e-mail: g.belzecki@ifzz.pan.pl
} 


\section{MATERIAL AND METHODS}

The ciliate Diploplastron affine was isolated from natural rumen fauna and grown in vitro or in the rumen of monofaunated sheep. To determine the effect of chitin on population density, the protozoa were grown in vitro in "caudatum" culture medium (Coleman et al., 1972) consisting of, g/l: $\mathrm{K}_{2} \mathrm{HPO}_{4} 6.3, \mathrm{KH}_{2} \mathrm{PO}_{4}$ 5.0, $\mathrm{CaCl}_{2} \cdot 7 \mathrm{H}_{2} \mathrm{O} 0.09, \mathrm{MgSO}_{4} \cdot 6 \mathrm{H}_{2} \mathrm{O} 0.09, \mathrm{CH}_{3} \mathrm{COONa} 0.75$, and $\mathrm{NaCl} 0.65$. They were cultivated for 28 days and counted every 4 days according to Michałowski et al. (1986). The provided feed consisted of meadow hay and wheat gluten supplied in a proportion of 0.3 and $0.08 \mathrm{mg} / \mathrm{ml}$ culture/d and was supplemented with 5 different doses of chitin.

The protozoa growing in the rumen were purified by the sedimentation method (Michałowski et al., 2003) and used to produce a crude enzyme preparation after killing the intracellular bacteria by an overnight incubation of the ciliates with chloramphenicol, streptomycin and ampicillin $(50 \mu \mathrm{m} / \mathrm{ml})$. The ability of ciliates to digest chitin, chitin derivatives, and murein was determined either according to Miller et al. (1960) or by measurement of the drop in optical density of the reaction mixture, respectively. Lysozyme activity was also identified by the lysoplate assay according to Osserman and Lawlor (1966).

\section{RESULTS AND DISCUSSION}

The supplementation of feed with chitin resulted in an increase in the population density and the size of this increase was related to the chitin dose (Figure 1). These findings suggest, therefore, that chitin improved the growth conditions required by Diploplastron affine. One of the possible explanations would be the enrichment of the culture medium with a source of energy available to ciliates.

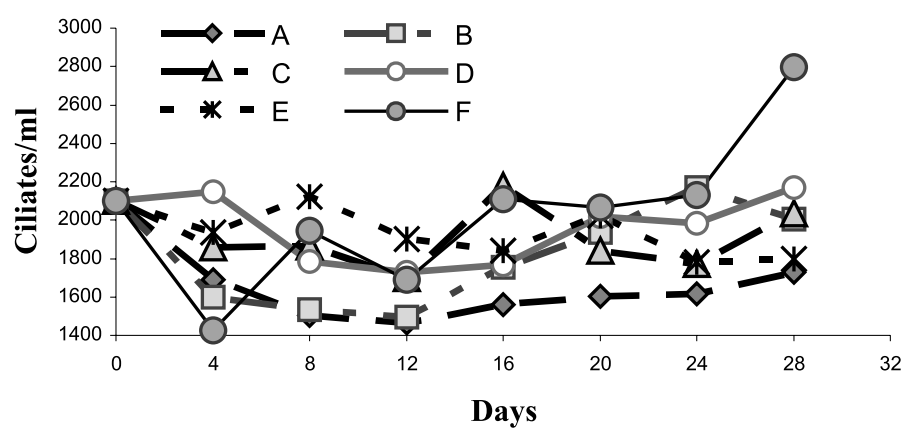

Figure 1. Changes in the number of Diploplastron affine in the cultures fed hay $(0.3 \mathrm{mg} / \mathrm{ml} / \mathrm{d})$ and wheat gluten $(0.08 \mathrm{mg} / \mathrm{ml} / \mathrm{d})$ alone-A or with the same doses of hay and wheat gluten supplemented with $0.015-\mathrm{B}, 0.03-\mathrm{C}, 0.06-\mathrm{D}, 0.12-\mathrm{E}$ and $0.24 \mathrm{mg}$ chitin $/ \mathrm{ml} / \mathrm{d}-\mathrm{F}$, respectively 


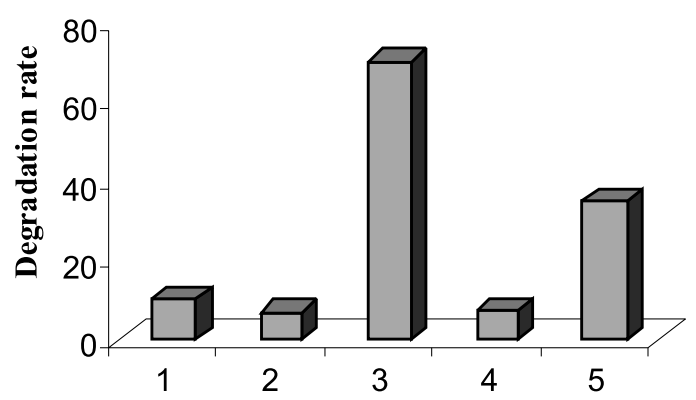

Figure 2. Degradation rate (mM of released product/mg protein/h) of chitosan - 1, chitin - 2, 4nitrophenyl N-acetyl glucosaminide - 3, 4-nitrophenyl N-acetyl galactosaminide - 4 and murein (drop in optical density) - 5 in the presence of a crude preparation from the cells of ciliates Diploplastron affine (mean values, $\mathrm{n}=3$ )

The incubation of chitin and chitosan with the protozoal crude enzyme preparation caused a release of reducing sugars (Figure 2). This suggests the presence of depolymerases in the examined preparation (Williams and Withers, 1990). On the other hand, the ability of the crude enzyme preparation to degrade both 4-nitrophenyl $\mathrm{N}$-acetylglucosaminide and 4-nitrophenyl N-acetyl-galactosaminide showed that disaccharidases like chitobiases were also present.

The digestion rate of murein was determined by measurement of the drop in optical density of the reaction mixture and confirmed by the lyso-plate assay of Osserman and Lawlor (1966). These findings confirm the ability of Diploplastron affine to degrade polysaccharides from bacterial cell walls (Figure 3).

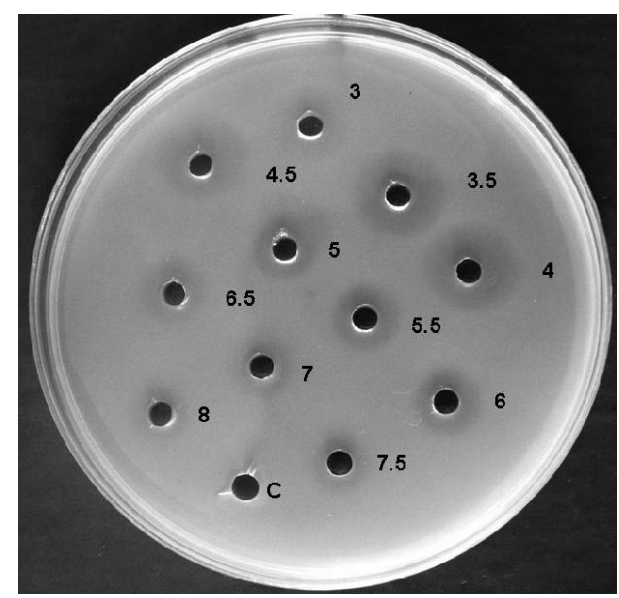

Figure 3. Visualization of lysozyme activity by the lyso-plate assay. The dark zones around of sample wells (black) resulted from the lysis of Micrococcus lysodeikticus cells added to the agar layer. $\mathrm{C}$-control. The $\mathrm{pH}$ of the applied preparation ranged between 3 and 8 


\section{CONCLUSIONS}

Chitin supplemented to the culture medium improved growth of the rumen ciliates, Diploplastron affine, in vitro. The enzymatic assay confirmed the ability of the ciliates to digest this polysaccharide. These findings suggest, therefore, that the positive effect of chitin could result from its role as an additional source of energy available for ciliates. Chitin was perhaps ingested and digested by protozoa and this was followed by utilization of the digestion products in energy yielding processes. Fermentation experiments are, however, necessary to confirm this hypothesis. Similarly, the role of murein in ciliate nutrition needs further studies.

\section{REFERENCES}

Coleman G.S., Davies J.I., Cash M.A., 1972. The cultivation of rumen ciliates Epidinium ecaudatum and Polyplastron multivesiculatum in vitro. J. Gen. Microbiol. 75, 509-521

Michałowski T., Bełżecki G., Kwiatkowska E., Pająk J.J., 2003. The effect of selected rumen fauna on fibrolytic enzyme activities, bacterial mass, fibre disappearance and fermentation pattern in sheep. J. Anim. Feed Sci. 12, 45-64

Michałowski T., Szczepkowski P., Muszyński P., 1986. The nutritive factors affecting the growth of the rumen ciliate Diploplastron affine in vitro. Acta Protozool. 25, 419-426

Miller G.L., Blum R., Glennon W.E., Butron A.L., 1960. Measurement of carboxymethylcellulase activity. Anal. Biochem. 2, 127-132

Morgavi D.P., Sakurada M., Tomita Y., Onodera R., 1996. Electrophoresis forms of chitinolytic and lysozyme activities in rumen protozoa. Curr. Microbiol. 32, 115-118

Osserman E.F., Lawlor D.P., 1966. Serum and urinary lysozyme (muraminidase) in monocytic and monomyelocytic leukemia. J. Exp. Med. 124, 921-951

Williams A.G., Coleman G.S., 1992. The Rumen Protozoa. Springer-Verlag, New York

Williams A.G., Wihers S.E., 1990. Effect of ciliate protozoa on the activity of polysaccharidedegrading enzymes and fibre breakdown in the rumen ecosystem. J. Appl. Bacteriol. 70, 144155 